\title{
0-285 当科で治療を行った上顎洞扁平上皮癌症例の検討
}

○池田雅一、鈴木政博、小林徹郎、仲江川雄太、川瀬友貴、松塚 崇、室野重之

福島県立医科大学 医学部 耳鼻咽喉科

【はじめに】上顎洞癌は局所進行病変で発見されることが多く、当科では局所制御率の向上を目的として術前に動注放射 線治療を行ってきた。当科の上顎洞扁平上皮癌症例に対する治療成績を遡及的に検討した。【対象と方法】2005年 1 月から 2017年12月までに当科で一次治療を行った上顎洞扁平上皮癌症例を対象とした。対象症例は29例。年齢は中央值63歳（44〜 86歳)、男女比は男性 27 例女性 2 例。観察期間は中央值27カ月（2 137カ月）。TNM 分類は cT3/T4a/T4b：4/14/11、cN0/ N1/N2a/N2b/N2c/N3：21/4/0/2/2/0であり、遠隔転移は 1 例であった。術前に動注放射線治療を施行した手術症例（術 前動注群）は12例（41.3\%）だった。主要評価項目は全生存率（OS）とした。副次的評価項目は術前動注群の無病生存率 (DFS)、局所制御率 (LCR)、切除標本の病理組織学的な治療効果について調査した。【結果】全症例の全生存率は 3 年 OS : $57.5 \%$ であった。術前動注群の 3 年 OS91.7\%、3 年 DFS 66.7\%、3 年 LCR 82.5\%であった。【結論】術前動注群は適応と なる症例が制限されるが、治療効果は良好であった。

\section{0-286トラニラストによる Transoral Laser Microsurgery 術後肉芽形成防止効果の検討}

○荒木幸仁、山崎直弥、冨藤雅之、宇野光祐、木村栄子、廣川祥太郎、長谷部正之、塩谷彰浩 防衛医科大学校 耳鼻咽喉科

早期声門癌に対する $\mathrm{CO}_{2}$ レーザーを用いた経口的切除術 Transoral laser microsurgery (TLM) は、機能温存治療の選択肢 の一つとして重要である。治療成績は放射線治療と同程度で、治療期間が短いなどの利点があるが、術後音声の悪化を来す 場合がある。声带での瘏痕形成、粘膜波動阻害が原因となるが、特にTLM 術後では過剩な㿍痕形成から肉芽形成を一過性 に認めることが多い。トラニラストはアレルギー疾患やケロイド痏痕に適応を有し、当科では TLM 術後の多くの症例に投 与してきた。今回 TLM 術後肉芽形成とトラニラスト内服の相関について検討した。

2010～2016年にTLM を施行した90症例において、トラニラスト内服を術後 4 週間以上継続した65症例（内服良好群）と 継続しなかった 25 症例（内服不良群）を比較検討した。術後 4 週間後の肉芽形成を評価したところ、内服良好群の $30.8 \%$ 、 内服不良群の $72.0 \%$ に肉芽形成を認め、内服不良群で有意に高かった。肉芽消失までの期間には有意差を認めなかった。卜 ラニラストは TLM 術後の肉芽形成を防止する効果が期待できる。

\section{0-287 下咽頭進展頸部食道癌に対する ELPS を併用した喉頭温存手術}

○村有貴、渡邊昭仁、谷口雅信

恵佑会札幌病院 耳鼻咽喉科・頭頸部外科

頸部食道癌は進行癌として診断され、手術治療では喉頭全摘術を併せ行うことが多い。さらに頸部食道から下咽頭に進展 している癌では喉頭温存手術は難しいと考えられている。われわれは完全切除可能な頸部食道癌の下咽頭進展症例に対して 頭頸部表在癌で行われている ELPS を応用し、喉頭温存手術を行ってきた。本術式の有用性・実用性について報告したい。 症例と方法：2014年から2018年までに恵佑会札幌病院で頸部食道扁平上皮癌下咽頭進展と診断され ELPS を応用した喉頭温 存手術を行った症例は19例であった。手術手技、手術後の合併症さらには生存率について検討した。結果：再建臟器は食道 切除に合わせ、胃管と遊離空腸を行っていた。反回神経麻痺は 4 例に認め、内 3 例には気管切開が必要であった。 3 例中 2 例では気管孔閉鎖ができていた。観察期間の中央值は 27 月で、 3 年粗生存率は $71.5 \%$ あった。結語 : 頸部食道癌下咽頭 進展例に対し ELPS を併せ行う喉頭温存手術は、適応を厳格にすることで有用な治療選択肢になり得ると思われた。

\section{0-288 ELPS における PGA シート貼付の有用性}

福家智仁、山田弘之、金児真美佳、澤 允洋、上田航毅、小林大介 伊勢赤十字病院＼cjkstart頭頸部・耳鼻咽喉科

近年咽喉頭癌に対する内視鏡下経口的切除が普及し、ELPS の有用性についても多数報告されている。当院では2017年よ り消化器内科医と共に、内視鏡下での咽㘈頭癌の切除を行っており、切除部にはフィブリン糊を用いた PGA シートの貼付 を積極的に行っている。

PGA シートは肉芽組織の形成や組織の再生を促進する働きがあり、従来の生体材料にはない良好な操作性、創部との接 着性、術後の疼痛軽減、出血の予防から近年その有用性について報告されている。耳鼻咽䚐科領域では舌癌など口腔領域に おいて粘膜切除部への貼付している報告が多数ある。PGA シートが創部とよく接着して外界からの刺激を防ぐために術後 の疼痛が緩和されていると考えられている。PGA シートは生体内で加水分解されて吸収されるには約 15 週間必要とされて いるが、口腔手術に拈いて上皮化が進行するに従って辺縁から剥離していくことが多い。当科では細かく切り分けたPGA シートを貼付することで早期の脱落を予防している。口演では PGA シートの術後の追跡、経口摂取状況についても検討し たい。 


\section{0-289 頸部郭清術後肩機能の前向き観察研究}

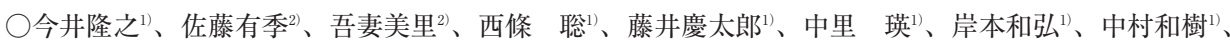
浅田行紀 ${ }^{1}$

宮城県立がんセンター＼cjkstart頭頸部外科1)、宮城県立がんセンターリハビリテーション室 ${ }^{2)}$

頸部郭清術後の肩機能障害は患者の術後の生活の質を著しく低下させる。その術後の肩機能障害の程度や経過、肩機能に 関する患者満足度などを評価、検討するため、倫理審査委員会の承認のうえ、前向き観察研究を行った。対象は2015年12 月〜2017年 7 月の間に当科で頸部郭清術を施行した症例のうち、文書による同意の得られた66症例。頸部郭清85側に対し て、術前、術後 1 力月、 3 力月、 6 力月、 9 力月、12 カ月に上肢挙上に抢ける外転角度の測定を行い、頸部郭清69側に関し て、術後 1 力月、 3 力月、 6 力月、9 カ月、12力月に打いて日本版 Western Ontario rotator cuff index(WORC) による患者 満足度調查を行った。外転角度は術前平均 165.6 度、術後 1 力月 96.5 度、 3 力月 110.1 度、6 力月 142 度、 9 力月 150.7 度、 12 カ月157.8度であり、術後12カ月でも術前と比較し有意な肩機能低下を認めた（p<0.05）が、経時的な改善を確認した。 WORC は術後 1 カ月に830.9、6 カ月674（p<0.05）と、術後6 カ月に有意な満足度の改善を認めた。最後に、リスク因子 との関連についても検討したので報告する。

\section{0-290 経口的咽喉頭悪性腫瘍手術（TOVS、ELPS）のために開発した新規可撓性器具の有用性}

○渡部佳弘 ${ }^{15)}$ 、岡本康秀 ${ }^{11} 、 今$ 西順久 ${ }^{25)}$ 、遠藤理奈子 ${ }^{1)}$ 、竹林带貴子 ${ }^{12}$ 、猪狩雄一 ${ }^{3)}$ 、小澤宏之 ${ }^{4)}$ 東京都済生会中央病院 耳鼻咽喉科 ${ }^{12}$ 、川崎市立川崎病院 耳鼻咽喉科 ${ }^{2}$ 、川崎市立井田病院 耳鼻咽喉科 ${ }^{3}$ 、 慶應義塾大学 医学部 耳鼻咽喉科 ${ }^{4)}$ 、国際医療福祉大学医学部耳鼻咽喉科頭頸部外科 ${ }^{5}$

消化器内視鏡技術の進歩により咽喉頭表在癌の診断例が増加し、経口的咽喉頭悪性腫瘍手術は増加傾向にある。消化器内 視鏡による ESD などの経口的手術のために、先端系電気メスや凝固止血鉗子、止血クリップなど多様な機器が開発されて いる。一方で、TOVS と ELPS のために作成された電気メスや鉗子などの手術機器は少なく、TLM や腹腔鏡手術などの機 器を流用することが多い。また、マリアブル針電極メスやサクションコアギュレーターなどは単回使用製品（高額）が多く 悪性腫瘍手術以外での使用は難しい。経口的咽喉頭手術に特化し、リユーザブルな器具をフジ夕医科器械と共同開発した。 今回開発した器具は、可撓性かつ再利用可能な電気メス $(25 \mathrm{~cm}) 、$ 先端回転鉗子 $(25 \mathrm{~cm})$ 、送水機能付サクションコアギュ レーター $(20 \mathrm{~cm})$ 。これらの器具とVIO3（ERBE）を用いることで経口的咽頭手術が効率的に行うことが可能になると思わ れた。これらの器具は経済性も向上し悪性腫瘍のみならず、良性疾患へも導入可能であり、経口的手術のさらなる発展に寄 与することが期待される。各器具の特徵および有用性を報告する。

\section{0-291 Endoscopic Laryngo-pharyngeal Surgery (ELPS) を施行した33症例の検討}

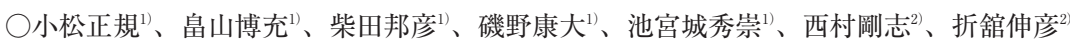
横浜市立大学附属市民総合医療センター 耳鼻咽喉科 ${ }^{12}$ 、横浜市立大学附属病院 耳鼻咽喉科・頭頸部外科 ${ }^{2}$

Endoscopic Laryngo-pharyngeal Surgery (ELPS) を施行した33症例、40手術について検討した。中咽頭癌が5件（すべて 後壁型)、下咽頭癌が35件（梨状窩：26件、後壁： 8 件、輪状後部：1件）であり、T分類は in situ/1/2=19/11/10であ り、切除断端は pHM0 : pHM1：pHMx が29：8：3、pVM0：pVM1：pVMxが36：3：1であった。術後経口摂取開始ま での期間は中央值で 5 日であり、手術合併症は喉頭浮腫が 5 件、皮下気腫・肺炎・術後出血がそれぞれ 1 件、嚥下障害の遷 延が 1 件で認められた。術後再発は 10 例で、局所が 7 例（手術同部位の新規病変も含む）、頸部リンパ節転移が 3 例、遠隔 転移が 1 例であった。局所再発例においては 7 例中 4 例で再度 ELPS を施行し、その後は再発を認めなかった。 2 年での疾 患特異的生存率、無再発生存率、局所制御生存率はそれぞれ97.0\%、75.1\%、78.3\%であった。ELPS 症例においては再発 例も少なくないが再手術で救済できる症例も多いため、頻回な上部消化管内視鏡検査や pHM1/pVM1 症例での 2nd-look 手 術などの慎重なフォローが望ましいと考えられた。

\section{0-292 咽喉頭表在病変に対する経口的手術の検討}

○弓井康平、上田 勉、築家伸幸、樽谷貴之、河野崇志、濱本隆夫、石野岳志、竹野幸夫 広島大学 医学部 耳鼻咽喉科・頭頸部外科

内視鏡診断技術の向上とともに、消化管領域同様に咽喉頭領域においても早期癌や前癌病変が発見される機会が増加して いる。手術侵襲の面や音声・言語などの機能温存、また放射線療法の担保などの面からも表在病変に対する治療法として経 口的手術が選択されることが多くなっている。今後もより高精度な診断技術、手術器具等の開発により経口的手術の適応は 拡大していくことが予想される。当院でも頸部リンパ節転移のない表在病変に対して耳鼻咽喉科医と内視鏡診療科医が協力 して経口的手術（主に endoscopic laryngopharyngeal surgery：ELPS）を行っている。今回、当院で施行した咽喉頭表在病 変に対する経口的手術症例について検討した。対象は2008年から2019年に咽喉頭表在病変に対して経口的手術を行った103 病変である。1）発見経緯 2）咽喉頭および上部消化管悪性腫瘍の既往 3）病変の部位 4）切除面積・厚み 5）術後合併症 6）術前診断・術後病理診断 7）局所再発の有無、および 8）術後の燕下機能について検討したので、若干の文献的考察を 加えて報告する。 